Feifei Li, Robert Sabella and David Liu eds., Nanking 1937: Memory and Healing

Armonk, N.Y., M.E. Sharpe, 2002, 278 pp.

Alain Roux

(2) OpenEdition

Journals

Electronic version

URL: http://journals.openedition.org/chinaperspectives/247

DOI: $10.4000 /$ chinaperspectives. 247

ISSN: 1996-4617

Publisher

Centre d'étude français sur la Chine contemporaine

Printed version

Date of publication: 1 February 2003

ISSN: 2070-3449

Electronic reference

Alain Roux, "Feifei Li, Robert Sabella and David Liu eds., Nanking 1937: Memory and Healing », China Perspectives [Online], 45 I january-february 2003, Online since 22 August 2006, connection on 22

September 2020. URL : http://journals.openedition.org/chinaperspectives/247 ; DOI : https://doi.org/ 10.4000/chinaperspectives.247

This text was automatically generated on 22 September 2020.

(C) All rights reserved 


\section{Feifei Li, Robert Sabella and David Liu eds., Nanking 1937: Memory and Healing}

Armonk, N.Y., M.E. Sharpe, 2002, 278 pp.

Alain Roux

\section{EDITOR'S NOTE}

Translated from the French original by Jonathan Hall

1 This small volume contains the papers presented at the international conference with the same title held on November 22nd 1997 at Princeton University. The participants at that conference took every care to be as scrupulous as possible in their approach to the major controversy that had been raging in China and Japan since the 1980s over the sacking of Nanking from December 13th 1937 to early March 1938, when it was still the capital of Nationalist China. This war crime, among several others, came before the Tokyo International Tribunal, which then passed sentence on 25 of the so-called firstranking war criminals. The latter included General Matsui Iwane, who had been commander-in-chief at the time. He was hanged on December 28th 1948. We know that the vicissitudes of the Cold War, which started during the thirty months taken by these endless trials, meant that 23 second-ranking war criminals, and 19 third-ranking ones, did not receive sentences and were mostly released by the end of 1948. These included Sasagawa Ryoichi, who set up a foundation in France which is still very active and honours his unpleasing memory. Such soft treatment by the Americans is in marked contrast with the comparative severity of the Nuremberg Trials, which passed judgment on Nazi war crimes before the beginning of the Cold War. And it certainly provided favourable ground for a campaign by the Japanese "denial" camp, which remained covert for a long time but then became increasingly open, as can be seen 
from publications like Tanaka Masaaki's What Really Happened in Nanking: The Refutation of a Common Myth, Sekai Shuppan Publications, Tokyo, 2000, 145 pp.

2 So this collection edited by Li, Sabella and Liu is to be welcomed as a necessary reminder of the reality of a massacre which cost the lives, often under appalling circumstances, of around 300,000 Chinese, of whom one-third were unarmed soldiers, and which was accompanied by the rape and murder of tens of thousands of women. In order to remove the burden of such deeds on the collective memory, along with the risk of their exploitation for political purposes, their reality must first of all be confronted. This is what the work does, with the greatest possible scrupulousness. Significantly, it includes contributions from many Japanese historians, which serves as a timely reminder that the Japanese "deniers" are mostly politicians and journalists, and that the scholarly community from that country only rarely shares their views. It is also worth remembering that the annual controversy over Japanese history textbooks is a politicians' war. It busts out at the end of every spring, when the cherry blossoms beautify the countryside and the profitable label of Ministry of Education approval is bestowed upon this or that work, allowing various right-wing figures to accuse the historians of having a "masochistic vision" of national history. That is why all the favoured textbook writers sing the same tune when dealing with the Nanking "incident" (jiken; or in Chinese shijian) by denying that it was a massacre (gyakusatsu; in Chinese, nüesha). On this record, it is very useful to consult Guido Samarani's remarkable report, "The Nanking Massacre in Some Japanese History Textbooks" in the 2001 issue of the Revue Bibliographique de Sinologie, pp. 3-6.

There are no such evasions in Memory and Healing. Here, not only does the remarkable bibliography provided with Takashi Yoshida's article ("Refighting the Nanking Massacre: the Continuing Struggle Over Memory") allow the careful reader to pursue further research (if he knows Japanese), but also the editors' concern for objectivity even means that space is provided for one of the few historians in the "denial" camp, Higashinakano Shudo ("The Overall Picture of the "Nanking massacre”, pp. 95-117). A reading of this reveals the general lines of the arguments by all such historians, to be found also in the aforementioned Tanaka Masaaki: viz. there is no direct testimony of the supposed massacres, particularly in the contemporary press; various frequently displayed photographs have been doctored; the communist authorities did not denounce these supposed massacres until the 1980s, in order to counteract the political consequences of opening the country to foreign influence, particularly from Japan. The same sophisms can be recognised at work in a recent article by a successful journalist to deny the September 11th attack on the Pentagon in Washington. If certain parts of the record are uncertain, that means the whole record is uncertain! And if it gets exploited politically, it must be a political fabrication! There is even the thesis put out by a certain Fujioka Nobukatsu, that the unarmed Chinese soldiers who had put on civilian clothes to avoid capture had thereby broken the Geneva Convention, and were therefore legitimately executed. Worse still, by their cowardly act they had thrown suspicion onto the civilian population, which had provoked certain excesses in response-which our scholar estimates at 47 people killed by mistake!

By contrast, the authors in this volume establish the facts in painstaking detail. In particular they show how the opening of the archives of the Yale Divinity School Library in 1997 gave access to the correspondence of American missionaries who were present in Nanking during the massacre. This includes the personal diary of John Rabe, 
which was published in Japan in 1997 and has since become widely known through Erwin Wickert's book, The Good Man of Nanking: The Diary of John Rabe (New York, Alfred Knopf, 1998). And the photographs in a book published in Chicago in 1996 by Shi Young and James Yin, The Rape of Nanking: An Undeniable History in Photographs were very carefully selected, so that all photomontages and dubious items were removed. So the "deniers" have resorted to outright documentary manipulation and falsification. Tanaka Masaaki, for example, deliberately rewrote or rearranged 900 sentences and words in the war diaries of General Matsui Iwane (whom he had served as secretary, by the way) to downplay the shock effect of the revelations about the atrocities contained in the journal of Nakajima Kesago, another general guilty of massacre, which was published in 1984. Lee En-han's article, "The Nanking Massacre Reassessed: A Study of the Sino-Japanese Controversy over the Factual Number of Massacred Victims" leaves no further room for doubt. I would add that there are no grounds for taking these facts beyond historically established limits, as the Peking authorities have sometimes done since setting up the memorial to the Nanking massacre in 1985, or as Inés Chang does in her provocatively entitled book, The Rape of Nanking: The Forgotten Holocaust of World War II (New York, Harper Collier, 1997). To cast the guilt on the Japanese people as a whole is just as dangerous and false as to try to deny the crimes committed by the Imperial soldiery in China. In this respect I would draw attention to the moving article by Haruko Taya Cook, "Reporting the Fall of Nanking and the Suppression of a Japanese Literary Memory of the Nature of a War". This deals with the work of the novelist Ishikawa Tatsuzo (1905-1985); as a reporter for the important paper Chu Koron, he followed a platoon of the Japanese army from November 2nd 1937 to early January 1938 in the Nanking region. He reported on this in March 1938, in a series entitled "Soldiers' Lives" (Ikiteiru heitai), which the censors immediately banned. These reports gave an unembellished account of the frenzied acts of murder and rape committed by the Japanese troops. 